\section{Hydrobiologia}

Volume 588, Number 1 / septembre 2007: 173-188

http://dx.doi.org/ 10.1007/s10750-007-0661-2

(C2007 Springer Science+Business Media
Archimer, archive institutionnelle de l'Ifremer http://www.ifremer.fr/docelec/

\title{
The intra-annual variability of soft-bottom macrobenthos abundance patterns in the North Channel of the Seine estuary
}

\author{
Nicolas Desroy ${ }^{1,2,{ }^{*}}$, Anne-Laure Janson ${ }^{1,3}$, Lionel Denis ${ }^{1}$, Gregory Charrier ${ }^{4}$, \\ Sandric Lesourd ${ }^{5}$ and Jean-Claude Dauvin ${ }^{1}$
}

(1) Station Marine de Wimereux, CNRS FRE, 28163 ELICO, BP 80, Wimereux, 62930, France

(2) Present address: Ifremer, Laboratoire Environnement et Ressources, 2 bis Rue Grout Saint Georges, BP 46, Saint Malo, 35400, France

(3) Laboratoire de Morphodynamique Continentale et Côtière, UMR 6143, Université de Rouen, 10 Boulevard De Broglie, Mont-Saint-Aignan Cedex, 76821, France

(4) Laboratoire de Ressources halieutiques, Institut Universitaire Européen de la Mer, Place Nicolas Copernic, Plouzane, 29280, France

(5) Université du Littoral-Côte d'Opale, CNRS UMR , 8013 ELICO, Avenue Foch, Wimereux, 62930, France

*: Corresponding author : Nicolas.Desroy@univ-lille1.fr

\begin{abstract}
:
Temporal and spatial variability of the Abra alba-Pectinaria koreni and Macoma balthica communities was examined in the northern part of the Seine estuary (North Channel) over different space and time scales in order to assess the role that the hydrologic regime and/or anthropogenic influences play in defining benthic communities over time. Sediment in the North Channel displayed strong spatial and temporal variability, sustained by intense sediment transport episodes. Total macrobenthic abundances ranged widely on the course of the year and there was no evidence of a seasonal signal for the density fluctuations, whatever the spatial scale considered. The bio-sedimentary dynamics can be divided into two periods: the first corresponds to the high flow rate period (January-May) during which fauna is influenced by fine silt/clay deposition, and the second to the low flow rate period (JuneDecember) during which sandy deposits prevail. Despite the absence of significant correlations between sediment composition and abundance, episodes of sediment transport seem to be an important structuring mechanism in the Seine estuary. As a consequence, the faunal composition varied throughout the year. The winter and spring fauna, characterised by species living on muddy fine-sands or muds, were enriched during the summer and autumn by species living in clean fine sand, such as Donax vittatus, Nephtys cirrosa or Spio decoratus, mainly represented by adult individuals. Secondary settlement of drifters may explain the rapid structuration of assemblages a few days after the sandy deposits. Our results suggest the importance of the bentho-pelagic coupling, primarily induced by the sedimentary instability, on the macrobenthic fauna dynamics. The intraannual variability of assemblages at the mouth of the Seine river and the silted situation of the North Channel might simply be the result of the silting up and alteration of the inner estuary, generated by several decades of man-made modifications and natural processes.
\end{abstract}

Keywords: Temporal variability - Bentho-pelagic coupling - Sediment - Abra alba community Anthropogenic impacts - Port 2000 


\section{Introduction}

Since the mid- $19^{\text {th }}$ century, industrial activities have been taking place in the lower part of the Seine estuary, with the attendant negative impact on the environment. The extensive management operations that have been carried out to "subdue" the estuary - including land reclamation, dyke construction, waste water drainage, and the dredging and sediment disposal needed to keep the navigable waterways accessible - have led to a decrease in the river channel width, a lessening of the seawater exchanges, and the progressive silting up of the inner part of the estuary (Lesourd et al., 2001). The estuary is also affected by the heavy input of organic matter in the sediment and industrial effluents. For example, the concentrations of heavy metals in the Seine estuary are among the highest found in the European estuaries, particularly with regard to cadmium and lead (Chiffoleau et al., 2001; Miramand et al., 2001). In the eastern part of the bay of Seine, in response to hydrodynamic and sedimentary gradients, two communities are distributed from the open sea to the coast: a muddy fine sand Abra alba-Pectinaria koreni community and a muddy Macoma balthica community (Cabioch \& Gentil, 1975). Although the macrobenthic communities along the inner estuary are well known (Elkaim et al., 1982; Thiébaut et al., 1997, Dauvin \& Desroy, 2005), data about the intra-annual changes in macrobenthos abundances are completely absent. However, according to Lesourd et al. (2003), such data is crucial to understanding how the estuary functions since sediment distribution is governed by seasonal meteorological and hydrologic variations and divided into two main successive periods. During winter, the fine-grained sediment supply is the result of high river discharge periods, amplified by ebb currents during spring tides. The mud deposit areas are then limited to the proximal outlet part of the estuary. The associated mean silt and clay content generally exceeds $75 \%$ in the topmost $10 \mathrm{~cm}$ of the superficial sediment. During low river flow, the fine-grained sediment accumulated in the estuary outlet are reworked by waves and tidal currents. A fraction of this material is scattered away to the Bay of Seine, the other part being transported landward into the estuary where it contributes to the deposition of estuarine mud. Suspended particulate matter has a tendency to settle in the lateral zones and in some sink holes. These residual deposits make up a superficial cover that contributes to the filling of the Seine outlet. These seasonal variations mainly depend on the intensity of the river discharge, but are also linked to wave activity. Such variability may strongly affect the magnitude of the processes which regulate benthic macrofauna from season to season (Seitz, 1998).

To this highly heterogeneous pattern of physical and chemical factors will be added the effects of the most recent infrastructure development along the Seine estuary, the extension of Le Havre harbour (Port 2000 project) near the mouth of the Seine river. Begun in 2002, plans for the North Channel include the construction of a channel (16 m deep, $350 \mathrm{~m}$ wide, and 2 $800 \mathrm{~m}$ long) connected to the habour's navigational channel, as well as the construction of a dam-protected basin (Dauvin et al., in press). Simulations have predicted that the harbour extension will have consequences on sedimentation in the estuary by increasing fine particle accumulation, thus reducing the intertidal zone in the North Channel and causing further damage to the Seine estuary as a whole (see Dauvin, 2002). Some compensatory measures, such as the construction of an artificial island for wild birds, and the dredging of a new canal in the upper part of the North Channel to maintain seawater circulation, are planned in order to limit the negative ecological effects of this new man-made modification of the Seine estuary (Hamm et al., 2001, Dauvin et al., in press).

Given this context, the present study had several objectives. The first, based on the sampling of the Northern Channel soft-bottoms in 2001 (i.e. before the extension of Le Havre harbour began), was two-fold: to determine whether or not the density, biomass and composition of benthic communities were subject to seasonal fluctuation or any other significant temporal 
variation, and to assess the ecological importance of this area in the estuary's functioning. The second objective was to examine the role of hydrologic regime and anthropogenic influence in defining benthic communities over time, using data from a 2002 study of a single site located in the centre of the Channel.

\section{Material and methods}

\section{Study area}

The Seine estuary is the largest megatidal estuary in the English Channel, covering about 150 $\mathrm{km}^{2}$ at high tide. As a result of extensive activities/public works operations, over the last hundred years, the river channel has shrunk and the seawater exchanges in the estuary have greatly decreased (see Lesourd et al., 2001 and Dauvin \& Desroy, 2005 for details). The average tidal range at the mouth is about $8.5 \mathrm{~m}$ for spring tides and $4.0 \mathrm{~m}$ for neap tides. The influence of seawater is increased by the estuarine morphology: the tide penetrates $70 \mathrm{~km}$ in from the coastline (to the Poses dam). River discharge (mean flow rate of $400 \mathrm{~m}^{3} . \mathrm{s}^{-1}$ ) varies seasonally, from a maximum of $2000 \mathrm{~m}^{3} . \mathrm{s}^{-1}$ in winter to a minimum of $100-200 \mathrm{~m}^{3} . \mathrm{s}^{-1}$ in summer (Guézennec, 1999). Like many European macrotidal estuaries, the Seine estuary is characterized by a zone of maximal turbidity with suspended matter concentrations from 1 to 10 g..$^{-1}$, generally located in the upper part of the estuary.

\section{Sampling designs}

Temporal changes in the composition and abundance of the macrobenthic invertebrate communities were studied in the Northern Channel before the work for the harbour extension began, from surveys conducted in February (26-28), June (5-7), September (26-28) and December (3-5) 2001. The macrobenthos was sampled at 11 sites in February, June and September and 10 sites in December $(4<$ water depth $<10 \mathrm{~m})$, site 61 being inaccessible due to harbour maintenance work (Figure 1). Four sediment samples were collected using a $0.25 \mathrm{~m}^{2}$ Hamon grab, with replicates collected within a $50 \mathrm{~m}$ range of each site, according to DGPS positioning. Sub-samples of sediment $(5$ superficial $\mathrm{cm}$ ) were taken from additional grab samples and subsequently analysed for grain size distribution (wet sieving) and organic matter content (weight loss of sediment dried at $600^{\circ} \mathrm{C}$ for $6 \mathrm{~h}$ ).

Site 62, which was sampled during 2002, was chosen in order to determine whether the benthic abundance patterns observed in the Channel were influenced mainly by natural factors (such as hydrology) or mainly by the disturbances associated with the harbour extension, and to classify the factors responsible for the observed changes. Its location at the centre of the North Channel and its distance from the harbour extension work, had protected the estuary bottoms from direct influence. To assess the influence of the high and low flow rate periods of the Seine river, the sampling frequency was $\approx 15$ days from March to June 2002 and 2-3 months from June to December (Figure 2). Unfortunately, a different sampling gear, a Van Veen grab, has to be used in 2002. To avoid doubt on inter-annual differences due to the use of these two grabs, species area curve specifications were considered. The minimal areas to sample $80 \%$ of species depended on the gear used $\left(0.3\right.$ to $0.4 \mathrm{~m}^{2}$ for the Van Veen grab depending on the season and $0.75 \mathrm{~m}^{2}$ for the Hamon grab). As a result, to allow a meaningful measurement of local biodiversity because of the habitat heterogeneity, a minimal number of four replicates (whatever the gear considered) was necessary. Then, five replicate sediment samples were collected with a $0.1 \mathrm{~m}^{2}$ Van Veen grab for the benthos study. At each date, an additional grab was used to determine grain-size distribution (5 top $\mathrm{cm}$ of sediment), and a Reineck box core $\left(1 / 58 \mathrm{~m}^{2}\right)$, from which one rectangular sub-core $(14 \mathrm{~cm}$ x $8 \mathrm{~cm} \mathrm{x} 10-35 \mathrm{~cm}$ deep depending on the sediment) was taken, was used for the lithological description. 
In all cases (both the 2001 and 2002 surveys), the benthic samples were sieved through a 1$\mathrm{mm}$ mesh in the field and preserved in buffered formalin. In the laboratory, samples were sorted after staining with Rose Bengal, identified to species level and counted.

\section{Data analysis}

A formal significance test for differences in sediment and benthic fauna compositions between seasons was performed using either the ANOSIM randomisation/permutation test implemented in the PRIMER package (Clarke, 1993) or the variance analysis (ANOVA) following Bartlett test for variance homogeneity (Scherrer, 1984). Two granulometric classes, dominant in the Seine estuary sediments (Lesourd et al., 2003), were chosen for graphic representations and data analysis. According to the Larsonneur (1977) classification, these sediments belong to the silt/clay class (particles $<63 \mu \mathrm{m}$ ) and the upper fraction of fine sand class $(100 \mu \mathrm{m}<$ particles $<200 \mu \mathrm{m})$. Changes in assemblages and in sediment characteristics were visualized through non-metric multidimensional scaling (MDS) plots based on triangular matrices of the Bray-Curtis similarities implemented in PRIMER (Clarke \& Warwick, 1994). Prior to ordination, $\log (x+1)$ transformations were performed on the benthic species abundance data. Patterns in the fauna distribution were linked to the environmental variables using the BIOENV routine in PRIMER. Finally, a t-test for paired samples was used to assess the inter-annual changes at site 62 and the summed cumulated function was used to characterize the bio-sedimentary dynamics in 2002. This last method consist of substracting a reference value (here, the mean of the series) from each of the data, and to successively add residuals to form a cumulative function [see Ibanez et al. (1993) for more details]. The graph of this function gives directly dates, intensity and duration of any changes.

\section{Results}

Seasonal changes in the North Channel (year 2001)

Patterns of sediment distribution

Fine sediments, globally ranging from muds to fine sands depending on the season, were dominant in the North Channel throughout the year. Although silt/clay $(<63 \mu \mathrm{m})$ and fine sand $(100 \mu \mathrm{m}<$ particles $<200 \mu \mathrm{m})$ were the principal granulometric classes, the high mud content of sediments, reaching values of up to $50 \%$ in $45 \%$ of the sites in February, June and September, underlined the general silted situation of the channel (Figure 3). Spatial changes in the overall sediment composition were significant (ANOSIM, $r=0.458 ; \mathrm{p}<0.001$ ). Independently of any longitudinal gradient, mud and fine sand distribution patterns exhibited a high spatial heterogeneity, given that the percentages of mud or fine sand in sediment ranged from 5-25\% to more than $80 \%$ in adjacent sites. The sediment composition also varied temporally, as shown by changes in silt/clay or fine sand content in the sediment throughout the year (Figure 3). Seasonal changes in silt/clay and fine sand content were drastic and asynchronous from one season to another; for example, at site 16 or sites 61 and 62, large sand deposits were observed in December and in September, respectively. Some sites were also characterised by the temporary presence of pebbles (site 60 in February and December and site 56 in September). The overall statistical analysis (North Channel scale, i.e. sites pooled) of seasonal variability did not integrate the changes occurring at each site and thus was not significant (ANOSIM, $r=-0,06 ; \mathrm{p}>0.05$ ).

Despite seasonal variations, the organic matter content of sediments remained less than $6 \%$, except at sites 56 and 59 where values reached 9\% in June and 11\% in February, respectively. 
A total of 115 taxonomic groups were collected from the samples (62 sp. - February, 56 sp. June, 61 sp. - September, and 80 sp. - December). With 60 species (52.2\% of the macrobenthic species), the polychaetes were the most diverse taxon. Mollusks comprised 23 species (20.1\%); crustaceans, 22 species (19.1\%); echinoderms, 5 species (4.3\%); and anthozoans, nemertineans, phoronidians and sipunculids comprised 5 species. The species with the highest occurrence frequency included the polychaetes Nephtys hombergii (present in 97.7\% of samples) and Aphaelochaeta marioni (77.2\%), and the mollusc Abra alba (77.2\%).

Total macrobenthic abundances varied from 0.5 to 942.6 ind.0.25 $\mathrm{m}^{-2}$ in February, 2.2 to 462.7 ind. $0.25 \mathrm{~m}^{-2}$ in June, 1.0 to 752.5 ind. $0.25 \mathrm{~m}^{-2}$ in September, and 1.2 to 834.5 ind. $0.25 \mathrm{~m}^{-2}$ in December (Figure 4). Molluscs (especially Abra alba and Mysella bidentata) were the dominant fauna in every season (59.4\% - February, 51.0\% - June, 69.7\% - September and $57.5 \%$ - December).

In spite of a marked intra-site variability due to the patchily distribution of dominant species as the polychaete Aphaelochaeta marioni and Owenia fusiformis or the molluscs Mysella bidentata, in February, June and September, species richness and abundances tended to increase along an upstream - downstream gradient in the Channel, with site 16 exhibiting the highest densities [from 462.7 to 942.6 ind.0.25 $\mathrm{m}^{-2}$ (Figure 4)]. No clear seasonal trend was observed in abundance; values were stable in February, June and September and highly varied from September to December, with the highest abundances being observed in the central part of the Channel (Figure 4). The Shannon diversity index remained low (between 0.2 and 1.1) at each site throughout the year, reflecting the unbalanced distribution of individual species abundances. A relatively small number of species (Abra alba, Aphaelochaeta marioni and Mysella bidentata) strongly dominated a fairly diverse fauna.

Congruently with the spatial heterogeneity of sediment distribution, the structure of invertebrate assemblages also exhibited differences along the Channel, regardless of the season (ANOSIM, $r=0.674$; $\mathrm{p}<0.001$ ). A MDS analysis of the variability of the benthic faunal abundances highlighted a continuum within the muddy fine sediments, from an upstream zone (sites 61, 62, 63 and 64) characterized by a depauperate fauna, regardless of the season considered (usually $<50$ ind. $0.25 \mathrm{~m}^{-2}$ ) to a downstream zone (sites 16, 56, 57, 58, 59 and 60) in which faunal density was higher and time-dependent. Site 17, which is a continuation of the intertidal sandbanks, and whose sediment sheltered low abundances of fine sand preferring species, is isolated (Figure 5). However, due to the high variability of the samples, no significant seasonal differences could be determined (ANOSIM, $r=0.005$; $\mathrm{p}>0.05)$.

Despite the absence of significant correlations between abundance values and sedimentary composition (BIOENV analysis), sediment dynamics, especially the rapid deposition/erosion phenomena, need to be taken into account to understand the changes in abundance. The abundance decrease observed at site 16 from September to December can be explained by the fine sand content, which increased from $7.1 \%$ to $75.7 \%$ in sediment. Similarly, following the change from fine sand to pebbles at site 60 between September and December, the benthic community changed radically from a sand-preferring infauna to a large mussel bed.

\section{Seasonal changes at site 62 (year 2002)}

\section{Sediment composition}

Whatever the date considered, silt/clay and fine sand granulometric classes at site 62 comprised more than $90 \%$ particles, with silt and clay being dominant [content $>70 \%$, except 18 June (Table 1)]. No trend can be detected from the high to the low flow rate periods since, excepted the value of $65 \mu \mathrm{m}$ reached on 18 June, the mean grain size remained stable through the year, ranging from $15.4 \mu \mathrm{m}$ to $24.0 \mu \mathrm{m}$. Grain size stability was sometimes punctuated by 
rapid changes, as witnessed by the important and temporary (since the initial conditions were rapidly recovered) deposition of sand observed on 18 June.

\section{Lithofacies}

Due to flood deposits, site 62 was influenced in the spring by thin (2 cm max.) deposits (i.e. after strengthening processes). As shown in Figure 6, the sediment on 23 March was characterized by a 1-cm surficial deposit of mud, probably eroded during the highest levels of flooding (22-28 March), since the mud had disappeared by 2 April. On 22 April, the core, collected on an eroded surface, exhibited a recently deposited layer of mud (1-cm thick), still present on 2 May though reduced in thickness. This layer was topped by new deposits of homogeneous soft mud on 16 May $(2 \mathrm{~cm})$ and 30 May $(<1 \mathrm{~cm})$. These muddy sediments were covered by a heavy deposit of three grades of sand (fine, muddy fine and medium) on 18 June. This sandy deposit was presumably eroded over the summer, since only a fine layer of medium to fine sand with shells (probably deposited in June) covered the layer of stiff mud and interlaminated silty beds observed on 30 May. The autumnal period (from 29 September to 3 December) was characterized by a thick deposit of sand $(\approx 15 \mathrm{~cm})$.

\section{Patterns of faunal abundance}

A total of 36 species was collected at site 62 over the year. The fauna was composed of annelids (17 sp.), arthropods (10 sp.), molluscs (9 sp.) and cnidarians (1 sp.) and was dominated, in number of individuals, by polychaetes (63.0\%) and molluscs (34.2\%).

Total abundances remained low throughout the year [minimal and maximal values of $5.8 \pm 5.1$ and $63.8 \pm 55.8$ ind.0.1 $\mathrm{m}^{-2}$, respectively (Figure 7)]. As noticed previously in 2001, the variability between replicates may be pronounced depending on the sampling date, evidencing the existence of a small scale heterogeneity due to local sediment deposits. Although values varied significantly over the year (ANOVA, $\mathrm{p}<0.001$ ), total abundance values revealed no seasonal trend since the maximal values were observed in April, June and December. Changes in abundance were related to the sand deposits occurring during the period with the lowest flow rate level. The function of the summed cumulated densities and the silt/clay and fine sand particle contents indicated that the bio-sedimentary dynamics could be divided into two periods: the first from March [and maybe January (pers. obs.)] to May during which fauna was influenced by fine silt/clay deposits (usually associated with a sediment compaction phenomenon), and the second, from June to December during which sandy deposits prevailed (Figure 8). As a consequence, the faunal composition changed over the year. The March to May fauna, characterised by an impoverished form of the Abra alba-Pectinaria koreni muddy fine sand community, was enriched from June to December by species living in clean fine sand, such as Donax vittatus, Nephtys cirrosa or Spio decoratus (Table 2). These latter species, mainly represented by adult individuals (pers. obs.), were the top three taxa on 18 June. Changes in fauna occurred very rapidly during this period, given that $\approx 15$ days were enough to replace a mud-preferring fauna by species with an affinity for clean fine sands. In December, a mixed assemblage, combining species of the A. alba and the N. cirrosa clean fine sand communities, was observed.

\section{Interannual variability at site 62}

We compared sedimentary and faunal changes observed in 2002 at site 62 to those observed in 2001 (Figures 9a and b). The proportion of sand was significantly higher in 2001 (t-test, $\mathrm{p}<0.05$ ), with maximal proportions observed in September (81.7\%) and December $(69.8 \%)$. Such differences did not influence total abundance values, which, with the exception of the high values recorded in December 2002 (63.8 555.7 ind.0.1 $\left.\mathrm{m}^{-2}\right)$, remained significantly 
consistent over the two years and displayed the same order of magnitude (t-test, $\mathrm{p}>0.05$ ), although varying greatly from one replicate to another.

\section{Discussion}

The soft-bottom macrobenthic communities in this study are comparable both in density and composition to other shallow-water communities of temperate estuaries (Warwick \& Uncles, 1980; Dittmer, 1981; Elkaïm et al., 1982; Ysebaert et al., 1998; 2000; 2003). They evolve from the Abra alba-Pectinaria koreni muddy fine sand community, located in the downstream part of the North Channel, to the Macoma balthica oligospecific community, spread over the inner bottoms (Cabioch \& Gentil, 1975; Elkaïm et al., 1982, see Dauvin \& Desroy, 2005 for details). In this study, a permanently impoverished sandy facies (site 17), characterised by the mollusc Donax vittatus and part of the Abra alba community, was identified for the first time in the Seine estuary in response to locally enhanced hydrodynamics.

Intra-annual variability of macrobenthic fauna

Understanding the patterns of estuarine systems is difficult because variations in both physical forcing functions and biota occur at all scales (Dethier \& Schoch, 2005). In many coastal systems, the main community structure parameters fluctuate according to the typical yearly cycle of coastal temperate waters, as has been shown by Bachelet et al. (2000) for the lagoons of Arcachon, Certes (French Atlantic coast) and Prevost (French Mediterranean coast); by Desroy \& Retière (2001) for the Rance estuary (French Channel coasts); and by Nonnis Marzano et al. (2003) for the Lesina lagoon (southern Adriatic Sea). Contrary to expectations, our study found no evidence of a clear seasonal signal, integrating spring and summer recruitment, for the abundance changes in soft-bottom communities in the North Channel. At the scale of the North Channel, the principal faunal variations occurred during the autumnal period: abundance values were consistent between sites in February, June and September 2001 and highly variable between September 2001 and December 2001, with the highest abundances observed in the central part of the Channel. In addition, benthic fauna exhibited strong differences: some sites had very high abundance levels while others displayed very low levels, this inter-site variability being supplied by a small scale heterogeneity which may be responsible for patchily distribution of the fauna. According to Elkaïm et al. (1982), our observation for the North Channel is also true for the Seine estuary. These fluctuations are probably related to the dynamics of superficial sediments, which, in the Seine estuary, depends mainly on tidal currents, which control the dispersion of fine sediment and especially fluid muds (Lesourd et al., 2003), river discharge as well as short but intense events like storms and the intensity of wave action associated (Lesourd et al., 2003). However, the lack of information about the intra-annual variability of subtidal benthic assemblages at scales higher than a single site, both for the Seine and for the other major Northern European estuaries prevents us from making comparisons that would improve understanding of estuarine functioning.

Sediment in the North Channel was characterised by a strong spatial and temporal variability, sustained by intense episodes of sediment transport. Deposition events, often temporary and mainly observed during low flow rate periods, appear to have disturbed community structure and possibly community functioning. However, the consequences for benthic assemblages depended on the sites and the periods considered; for example, abundance decreased at site 16 in December 2001 and increased at site 62 in June 2002. When abundance decreased after sediment deposition, it was impossible to determine whether these decreases were due to organisms dying after being buried (Elmgren et al., 1986; Bouma et al., 2001) or resuspended 
in the water column (Armonies, 1994; Olivier et al., 1996a). Studies on the polychaete Pectinaria koreni in the Seine estuary have shown that unsuitable sediments or the presence of bioturbators induce the active resuspension of recruits (Olivier et al., 1996b), thus decreasing abundances. On the other hand, the deposition of sandy sediments may also contribute to increases in species diversity and abundance by allowing settlements of new species that prefer fine sands. The sudden presence in our samples of adult individuals of sedentary or small species (Donax vittatus, Magelona johnstoni, Spio decoratus...) suggests the existence of secondary settlements of individuals on adjacent sandbanks from which resuspension and drifting is possible due to strong currents.

\section{Physical versus biological determinism}

The results concerning bio-sedimentary dynamics can be divided into two periods: the first from March (and maybe January) to May, during which fauna is influenced by fine silt/clay depositions (with an associated compaction phenomenon), and the second from June to December, during which sandy deposits prevail and mean particle size increases. Edaphic conditions were globally more stable during the period of maximal river discharge, with lithofacies showing the prevalence of strengthening phenomena (or sometimes erosion as shown by the presence of eroded surfaces) on silt/clay deposits; nonetheless, the impact of these phenomena on the fauna remained minor. Maximal disturbances, due to the succession of sandy deposition events, occurred during the low flow rate period. Such events can lead to rapid and drastic changes in composition and abundances, like those observed at site 62 on 18 June 2002. These results complete the observations of Elkaïm et al. (1982), who observed seasonal (winter/summer) differences within benthic assemblages at the scale of the estuary. Examining the periods of maxima and minima in terms of total macrofaunal abundance values showed no consistent pattern that would suggest a relationship between the intensity of river discharge (highest flood values: $2280 \mathrm{~m}^{3} \mathrm{~s}^{-1}$ in 2001 and $1800 \mathrm{~m}^{3} \mathrm{~s}^{-1}$ in 2002) and faunal abundances. No relationships or significant correlations could be established between the river flow rate (peak flood value, lowest flow rate value, instantaneous/average flow rate values) and the changes in silt/clay or sand content in the North Channel in 2001 or at site 62 in 2002. Despite the absence of significant correlations, episodes of sediment transport and deposition emerged as a primary community structuring variable with respect to benthic community density and composition. This absence of relationships underlines a major problem associated with relating environmental variables to biological variables: the lack of knowledge about how environmental factors affect the biota, and whether upper or lower extremes, or mean values must be considered (Edgar \& Barrett, 2002). Our results confirm those of McCarthy et al. (2000), who after studying the intra-annual variability of soft-bottom macrobenthic communities over a period of 25 months in shallow Hawaiian waters, concluded that there was no relationship between the macrofaunal density fluctuations and periods of increased runoff. As they reported, "each station studied, taken in isolation, could tell its own unique story", the common thread being the existence of sediment transport episodes as a key community structuring factor.

The effect of wind and wave events on the dynamics of benthic fauna could be more important than previously hypothesized. This seems especially likely given that, after strong storms, from 200000 to 400000 tons of sediments can be resuspended and redistributed throughout the estuary (Lesourd et al., 2003). A modeling of the fine sediment transport in the Seine estuary, showing that (1) wave resuspension is partially responsible for the northern drift of fine particles in the Eastern bay of the Seine, and (2) the residual flux of fine particles advected out of the Seine mouth is more correlated to meteorological events than to the river flow discharge (Le Hir et al., 2001), confirms this hypothesis. 
On the basis of a grid of 40 to 67 sites sampled in 1986, 1987, 1988 and 1991, Thiébaut et al. (1997) emphasized the spatio-temporal persistence of the Abra alba-Pectinaria koreni community in the eastern bay of Seine and underlined the importance of larval retention and sediment stabilization by the polychaete Owenia fusiformis to explain this persistence. Post settlement processes (e.g. food limitation and post-larval drifting) were presumed to greatly modify the primary settlement pattern, generating the spatial reorganization of the whole community (Olivier et al, 1996a; Thiébaut et al, 1996). For example, studies of Pectinaria koreni and Owenia fusiformis recruitment have shown that the larval settlement of both species is relatively independent of edaphic conditions and can not generate the distribution patterns of adult populations (Lambert, 1991). Such conclusions are not inconsistent with our results and suggest the importance of bentho-pelagic coupling - via the post-settlement processes primarily induced by sedimentary instability - on the macrobenthic fauna dynamics. Despite the variability existing at small scales of time and space, the Abra alba community remains stable at large spatial and temporal scales in the Seine estuary compared to other sites in the English Channel (Bays of Veys and of Morlaix) or in the south bight of the North Sea (Gravelines) where fluctuations are more pronounced (Dauvin, 2002). Paradoxically to the strong disturbing factors existing in the Seine estuary, the Abra alba community remains characterized by the absence of long term trend (Fromentin et al., 1997).

\section{Human impact}

Results from this study will also serve as a baseline for future studies examining the impact of the extension of Le Havre harbour on benthic communities and drawing conclusions about the abilities of the estuary to restore itself. However, assessing the human impact on benthic communities and on this communities' evolutionary trend is difficult since the polyhaline subtidal zone of the Seine estuary is characterized by large fluctuations in salinity, high current velocities and high turbidity. Moreover, rather than being superimposed on natural processes, human activities interfere with them. Although estuaries are known to be variable systems, the situation in the Seine estuary is exacerbed especially by the embankment of the Seine river and the the reduction in surface of the estuary. The high variability prevailing in the estuary makes it impossible to determine whether or not the harbour extension that began in January 2002 (essentially dredging/dumping operations) has modified the functioning of the benthic ecosystem. As observed in the Schelde estuary (Ysebaert et al., 2000), processes of sedimentation and resuspension will probably be enhanced by dredging ( 45 million tons for the shipping channel and 5 million tons for maintenance dredging). The inconsistent sediment dynamics observed at site 62 between 2001 and 2002 certainly reflects the industrial equipment in the North Channel but also the initial effects of the engineering work (dredging and enrockment) associated with the harbour extension. Despite the sedimentary variability, benthic fauna remain relatively unaffected and resilient. Congruently, studies carried out in 2002 by Dauvin et al. (in press) to assess effects of harbour infrastructure development show that one year into the harbour management plan, changes in benthic and suprabenthic assemblage abundance do not exceed the range of spatial variability that exists naturally in the Seine estuary, whereas the plan was expected to cause rapid changes. The intra-annual variability of the assemblages at the mouth of the Seine river and the silted situation of the North Channel might result from the silting up and the alteration of the inner estuary, which has been generated by several decades of man-made modifications and natural processes (Lafite \& Romana, 2001; Lesourd et al., 2001). Like the subtidal zone of the Zeeschelde (Ysebaert et al., 2000), the low abundance of the macrobenthos provides evidence of the fact that the North Channel is a highly stressed environment. The Shannon diversity index (less than 1.1 whatever the season considered) clearly showed that communities remain in the early stages of succession and under disturbance (Frontier, 1976). 
Although being an important juvenile fish feeding ground in the past, the subtidal bottoms in the North Channel have progressively became an area of little ecological interest, as illustrated by the low abundances of benthic invertebrates and mesozooplankton upstream. The main ecological highlight is the suprabenthic fauna, which was and remains an important trophic resource for higher consumers (especially fish) in the food web (Dauvin et al., in press). The adjacent intertidal mudflats, although known to be an important feeding ground for birds and juvenile fish, continue to regress due to increased silting up and colonization by halophytes. Expected modifications over the next few years, connected to the reduction of the width of the North Channel, include an erosion of the estuarine bottoms located between the new dock dam and the north dyke embanking the Seine river, and an accumulation of particles in the upper part of the North Channel, leading to the continued silting up of the intertidal mudflats. Initial field observations, conducted from 2002 to 2004, already confirm the erosion of downstream sediments in the North Channel and the emergence of pebbles on which large mussels beds are now settled. In order to minimize these hydro-sedimentary and biological changes, and to preserve the "Grande vasière" tidal flat located in the upper part of the North Channel, several compensatory actions are planned, to be implemented between 2004 and 2006 (Hamm et al., 2001). To be efficient, compensatory actions must integrate objective standards for these resources, which are independent of the existing altered condition. The objective must be restoring habitat and fauna diversity rather than maintaining the current conditions, since impact measurements that do not distinguish between changes to the existing environment and the desired condition of resource will fail to account for the cumulative decline of the quality of estuarine habitats (McCold \& Saulsbury, 1996).

\section{Acknowledgements}

This study was undertaken within the framework of the Seine-Aval programme, co-ordinated by the Haute Normandie Region, which supported A.L.J. by a doctoral fellowship. The authors are grateful to the crew of "R.V. Côte d'Aquitaine" for their aid during sampling, to L. Gomez-Gesteira for his valuable assistance in the laboratory, and to L. E. Spencer for comments and help in correcting the English version of this text. 


\section{References}

Armonies, W., 1994. Turnover of postlarval bivalves in sediments of tidal flats in Königshafen (German Wadden Sea). Helgoländer Meeresuntersuchungen 48 : 291-297.

Bachelet, G., X. de Montaudouin, I. Auby \& P.-J. Labourg, 2000. Seasonal changes in macrophyte and macrozoobenthos assemblages in three coastal lagoons under varying degrees of eutrophication. ICES Journal of Marine Science 57: 1495-1506.

Bouma, H., J.M.C. Duiker, P.P. de Vries, P.M.J. Herman \& W.J. Wolff, 2001. Spatial pattern of early recruitment of Macoma balthica (L.) and Cerastoderma edule (L.) in relation to sediment dynamics on a highly dynamic intertidal sandflat. Journal of Sea Research 45: 7993.

Cabioch, L. \& F. Gentil, 1975. Distribution des peuplements benthiques dans la partie orientale de la baie de Seine. Comptes rendus de l'Académie des Sciences 280: 571-574.

Chiffoleau, J.-F., D. Auger, E. Chartier, P. Michel, I. Truquet, A. Ficht, J.-L. Gonzalez \& L.A. Romanã, 2001. Spatio temporal changes in cadmium contamination in the Seine estuary (France). Estuaries 24: 1029-1040.

Clarke, K.R., 1993. Non-parametric multivariate analyses of changes in community structure. Australian Journal of Ecology 18: 117-143.

Clarke, K.R., R.M. Warwick, 1994. Changes in Marine Communities: An Approach to Statistical Analysis and Interpretation. Plymouth Marine Laboratory, Plymouth.

Dauvin, J.C. (coord.), 2002. Patrimoine biologique et chaînes trophiques. Programme Scientifique Seine Aval, fascicule 7. Editions IFREMER, Plouzané, France.

Dauvin, J.-C. \& N. Desroy, 2005. The food web in the lower part of the Seine estuary: a synthesis of existing knowledge. Hydrobiologia 540 (1-3): 13-27.

Dauvin, J.-C., N. Desroy, A.L. Janson, C. Vallet \& S. Duhamel, in press. Recent changes in estuarine benthic and suprabenthic communities resulting from the development of harbour infrastructure. Marine Pollution Bulletin.

Desroy, N. \& C. Retière, 2001. Long-term changes in muddy fine sand community of the Rance basin : role of recruitment. Journal of the Marine Biological Association of the United Kingdom 81: 553-564.

Dethier, M.N. \& G.C. Schoch, 2005. The consequences of scale: assessing the distribution of benthic populations in a complex estuarine fjord. Estuarine, Coastal and Shelf Science 62: 253-270.

Dittmer, J.D., 1981. The distribution of subtidal macrobenthos in the estuaries of the river Ems and Weser. In Wolff, W. (ed), Ecology of the Wadden Sea, Balkema, Rotterdam: 188206.

Edgar, G.J. \& N.S. Barrett, 2002. Benthic macrofauna in Tasmanian estuaries: scales of distribution and relationships with environmental variables. Journal of Experimental Marine Biology and Ecology 270: 1-24.

Elkaïm, B., F. Ibanez \& F. Proniewski, 1982. Le benthos subtidal de la Seine: analyse statistique des peuplements. Journal of Experimental Marine Biology and Ecology 64: 213252.

Ellingsen, K.E., 2001. Biodiversity of a continenetal shelf soft-sediment macrobenthos community. Marine Ecology Progress Series 218: 1-15.

Elmgren R., S. Ankar, B. Marteleur \& G. Ejdung, 1986. Adult interference with post larvae in soft sediments: the Pontoporeia-Macoma example. Ecology 67: 827-836.

Fromentin, J.-M., F. Ibanez, J.-C. Dauvin, J.-M. Dewarumez \& B. Elkaïm, 1997. Long-term variability of macrobenthic communities of the North-West French coast. Journal of the Marine Biological Association of the United Kingdom 77: 287-310. 
Frontier, S., 1976. Utilisation des diagrammes rang-fréquence dans l'analyse des écosystèmes. Journal de Recherche Océanographique 1: 35-48.

Guézennec, L. (coord.), 1999. Seine-Aval : un estuaire et ses problèmes. Programme Scientifique Seine Aval, Fascicule 1. Editions IFREMER, Plouzané, France.

Hamm, L., L.-A. Romana \& F. Lerat, 2001. Maintien des fonctionnalités biologiques de la vasière nord de l'estuaire de la Seine. Actes de Colloques de l'Ifremer 29: 157-167.

Ibanez, F., J.-M. Fromentin \& J. Castel, 1993. Application of the cumulated function to the processing of chronological data in oceanography. Comptes rendus de l'Académie des Sciences de Paris 316 : 745-748.

Lafite, R. \& L-A. Romaña, 2001. A man-altered macrotidal estuary: the Seine estuary (France): introduction to the special issue. Estuaries 24: 939.

Lambert, R., 1991. Recrutement d'espèces benthiques à larves pélagiques en régime mégatidal. Cas de Pectinaria koreni (Malmgren), annélide polychète. Thèse de doctorat, Université de Rennes, France.

Larsonneur, C., 1977. La cartographie des dépôts meubles sur le plateau continental français : méthode mise au point et utilisée en Manche. Journal de Recherche Océanographique 2: 3339.

Le Hir, P., A. Ficht, R. Silva Jacinto, P. Lesueur, J.-P. Dupont, R. Lafite, I. Brenon, B. Thouvenin \& P. Cugier, 2001. Fine sediment transport and accumulations at the mouth of the Seine estuary (France). Estuaries 24 : 950-963.

Lesourd, S., P. Lesueur, J.-C. Brun-Cottan, J.-P. Auffret, N. Poupinet \& B. Laignel, 2001. Morphosedimentary evolution of the macrotidal Seine estuary subjected to human impact. Estuaries 24: 940-949.

Lesourd, S., P. Lesueur, J.-C. Brun-Cottan, S. Garnaud \& N. Poupinet, 2003. Seasonal variations in the characteristics of superficial sediments in a macrotidal estuary (the Seine inlet, France). Estuarine, Coastal and Shelf Science 58: 3-16.

McCarthy S.A., E. A. Laws, W. A. Estabrooks, J. H. Bailey-Brock \& E. A. Kay, 2000. Intraannual variability in Hawaiian shallow-water, soft-bottom macrobenthic communities adjacent to a eutrophic estuary. Estuarine, Coastal and Shelf Science 50: 245-258.

McCold, L.M. \& J.W. Saulsbury, 1996. Including past and present impacts in cumulative impact assessments. Environmental Management 20: 767-776.

Miramand, P., T. Guyot, H. Rybarczyk, B. Elkaïm, P. Mouny, J.-C. Dauvin \& C. Bessineton, 2001. Contamination of the biological compartment in the Seine estuary by $\mathrm{Cd}, \mathrm{Cu}, \mathrm{Pb}$, and Zn... Estuaries 24: 1056-1065.

Nonnis Marzano, C., L. Scalera Liaci, A. Fianchini, F. Gravina, M. Mercurio \& G. Corriero, 2003. Distribution, persistence and change in the macrobenthos of the lagoon of Lesina (Apulia, southern Adriatic Sea). Oceanologica Acta 26: 57-66.

Olivier F., C. Vallet, J.-C. Dauvin \& C. Retière, 1996a. Drifting in post-larvae and juveniles in an Abra alba (Wood) community of the eastern part of the Bay of Seine (English Channel). Journal of Experimental Marine Biology and Ecology 199: 89-109.

Olivier F., N. Desroy and C. Retière, 1996b. Habitat selection and adult-recruit interactions in Pectinaria koreni (Malmgren) (Annelida: Polychaeta) post-larval populations: results of flume experiments. Journal of Sea Research 36: 217-226.

Scherrer, B, 1984. Biostatistique, Gaëtan Morin, Chicoutimi.

Seitz, R.D., 1998. Incorporation of soft-sediment systems into a model of marine benthic community regulation. Marine and Freshwater Research 49: 817-826.

Thiébaut, E., Dauvin, J.-C. \& Wang, Z., 1996. Tidal transport of Pectinaria koreni postlarvae (Annelida: Polychaeta) in the Bay of Seine (eastern English Channel). Marine Ecology Progress Series 138: 63-70. 
Thiébaut, E., Cabioch, L., Dauvin, J.C., Retière, C. \& Gentil, F., 1997. Spatio-temporal persistence of the Abra alba-Pectinaria koreni muddy-fine sand community of the eastern Bay of Seine. Journal of the Marine Biological Association of the United Kingdom 77: 11651185.

Warwick, R.M. \& Uncles, R.J., 1980. Distribution of benthic macrofauna associations in the Bristol Channel in relation to tidal stress. Marine Ecology Progress Series 3: 97-103.

Ysebaert, T., P. Meire, J. Coosen \& K. Essink, 1998. Zonation of intertidal macrobenthos in the estuaries of Schelde and Ems. Aquatic Ecology 32: 53-71.

Ysebaert, T., L. de Neve \& P. Meire, 2000. The subtidal macrobenthos in the mesohaline part of the Schelde estuary (Belgium): influenced by man? Journal of the Marine Biological Association of the United Kingdom 80: 587-597.

Ysebaert, T., P.M.J. Herman, P. Meire, J. Craeymeersch, H. Verbeek \& C.H.R. Heip, 2003. Large-scale spatial patterns in estuaries: estuarine macrobenthic communities in the Schelde estuary, NW Europe. Estuarine, Coastal and Shelf Science 57: 335-355. 
Table 1: Change in silt/clay $(<63 \mu \mathrm{m})$ and fine sand $(100 \mu \mathrm{m}>$ size particle $>200 \mu \mathrm{m})$ contents in sediment at site 62 in 2002.

\begin{tabular}{cccccccccc}
\hline Date & 23 March & 2 April & 22 April & 2 May & 15 May & 30 May & 18 June & 29 September & 3 December \\
\hline $\begin{array}{c}\text { \% of fine } \\
\text { sand } \\
\text { \% of }\end{array}$ & 7.55 & 2.85 & 0.57 & 3.61 & 0.68 & 0.40 & 31.71 & 7.11 & 18.25 \\
silt/clay & 83.61 & 91.28 & 95.05 & 90.82 & 94.48 & 93.43 & 50.67 & 85.39 & 70.19 \\
\hline
\end{tabular}


Table 2: Average abundances (ind.0.1 $\mathrm{m}^{-2}$ ) \pm SD of the first three most abundant macrobenthic species observed at site 62 between 23 March and 3 December.

\begin{tabular}{|c|c|c|}
\hline Sampling date & Three top ranked species & $\begin{array}{c}\text { Abundance (mean } \pm \text { SD } \\
\left.\text { ind.0.1m }{ }^{-2}\right)\end{array}$ \\
\hline \multirow{3}{*}{23 March } & Aphaelochaeta marioni & $9.4 \pm 9.4$ \\
\hline & Nephtys hombergii & $6.6 \pm 3.8$ \\
\hline & Macoma balthica & $1.8 \pm 1.8$ \\
\hline \multirow{3}{*}{2 April } & Mysella bidentata & $7.2 \pm 15.5$ \\
\hline & Pectinaria koreni & $6.6 \pm 5.2$ \\
\hline & Nephtys hombergii & $5.8 \pm 2.9$ \\
\hline \multirow{3}{*}{22 April } & Aphaelochaeta marioni & $15.0 \pm 6.2$ \\
\hline & Nephtys hombergii & $7.4 \pm 4.8$ \\
\hline & Streblospio shrubsolii & $4.6 \pm 3.9$ \\
\hline \multirow{3}{*}{2 May } & Aphaelochaeta marioni & $6.2 \pm 5.3$ \\
\hline & Nephtys hombergii & $5.8 \pm 2.6$ \\
\hline & Macoma balthica & $5.2 \pm 2.5$ \\
\hline \multirow{3}{*}{16 May } & Nephtys hombergii & $2.8 \pm 2.0$ \\
\hline & Macoma balthica & $1.8 \pm 0.8$ \\
\hline & Aphaelochaeta marioni & $1.0 \pm 1.7$ \\
\hline \multirow{3}{*}{30 May } & Macoma balthica & $3.4 \pm 1.8$ \\
\hline & Nephtys hombergii & $3.2 \pm 1.8$ \\
\hline & Heterocirrus alatus & $1.4 \pm 2.6$ \\
\hline \multirow{3}{*}{18 June } & Nephtys cirrosa & $7.2 \pm 2.3$ \\
\hline & Donax vittatus & $5.8 \pm 2.8$ \\
\hline & Spio decoratus & $5.0 \pm 4.8$ \\
\hline \multirow{3}{*}{29 September } & Pectinaria koreni & $3.4 \pm 2.9$ \\
\hline & Nephtys hombergii & $2.4 \pm 0.9$ \\
\hline & Macoma balthica & $1.2 \pm 1.1$ \\
\hline \multirow{3}{*}{3 December } & Mysella bidentata & $15.0 \pm 20.7$ \\
\hline & Pectinaria koreni & $13.4 \pm 10.4$ \\
\hline & Nephtys hombergii & $7.8 \pm 1.6$ \\
\hline
\end{tabular}




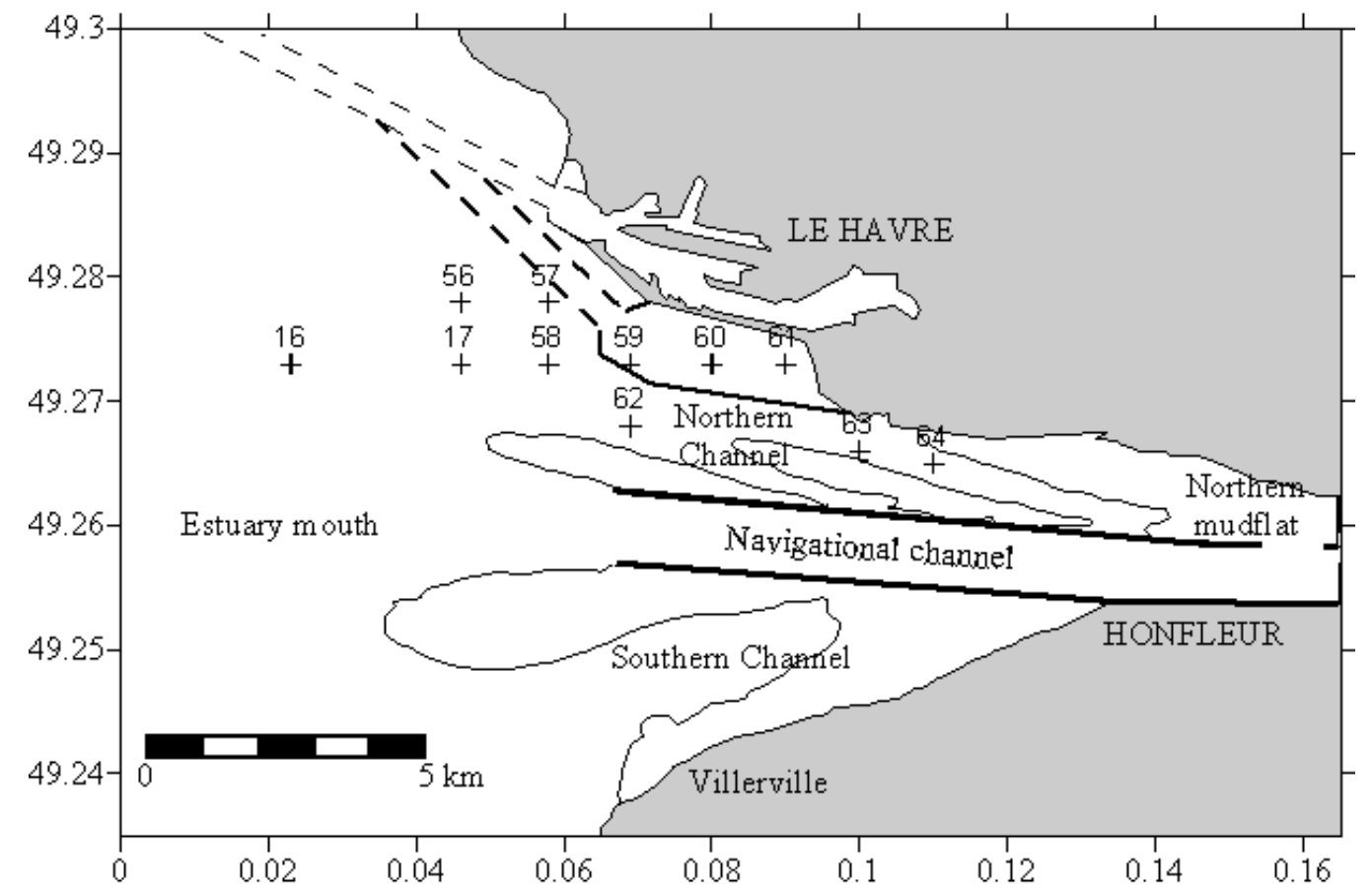

Figure 1 : Location of sampling sites. All sites were sampled in February, June, September and December (excepted site 61) 2001 and site 62 was sampled during the year 2002 (see figure 2 for frequency). Fine full lines: intertidal banks, full bold lines: dykes embanking the Seine river and location of the future dock (completion in 2005), doted lines : Main channel to Le Havre harbour (fine) and channel dredged to go to the future dock (bold). 


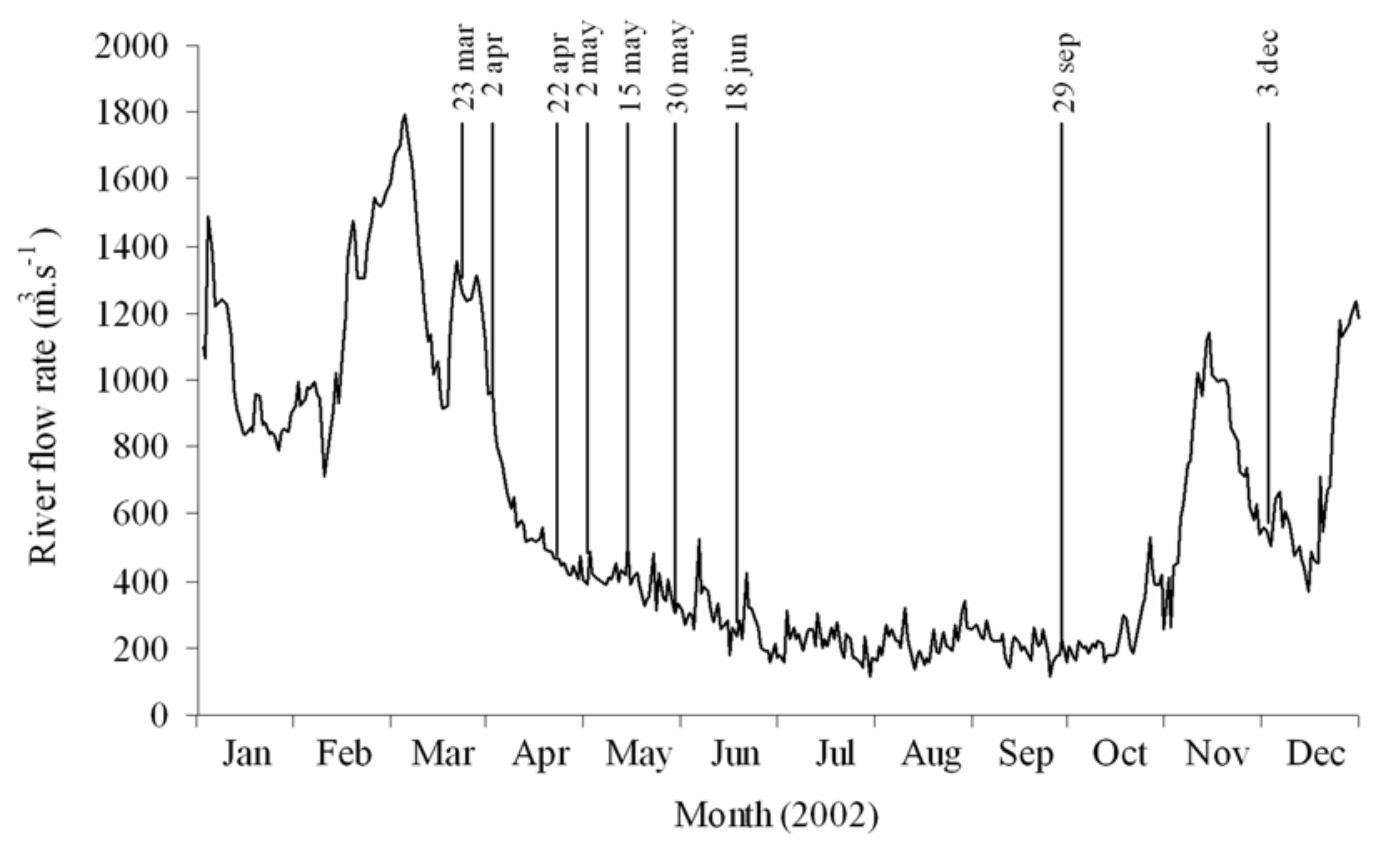

Figure 2: Sampling design conducted at site 62 with regard to the Seine flow rate (recorded at Poses at the entrance of the Seine estuary). 

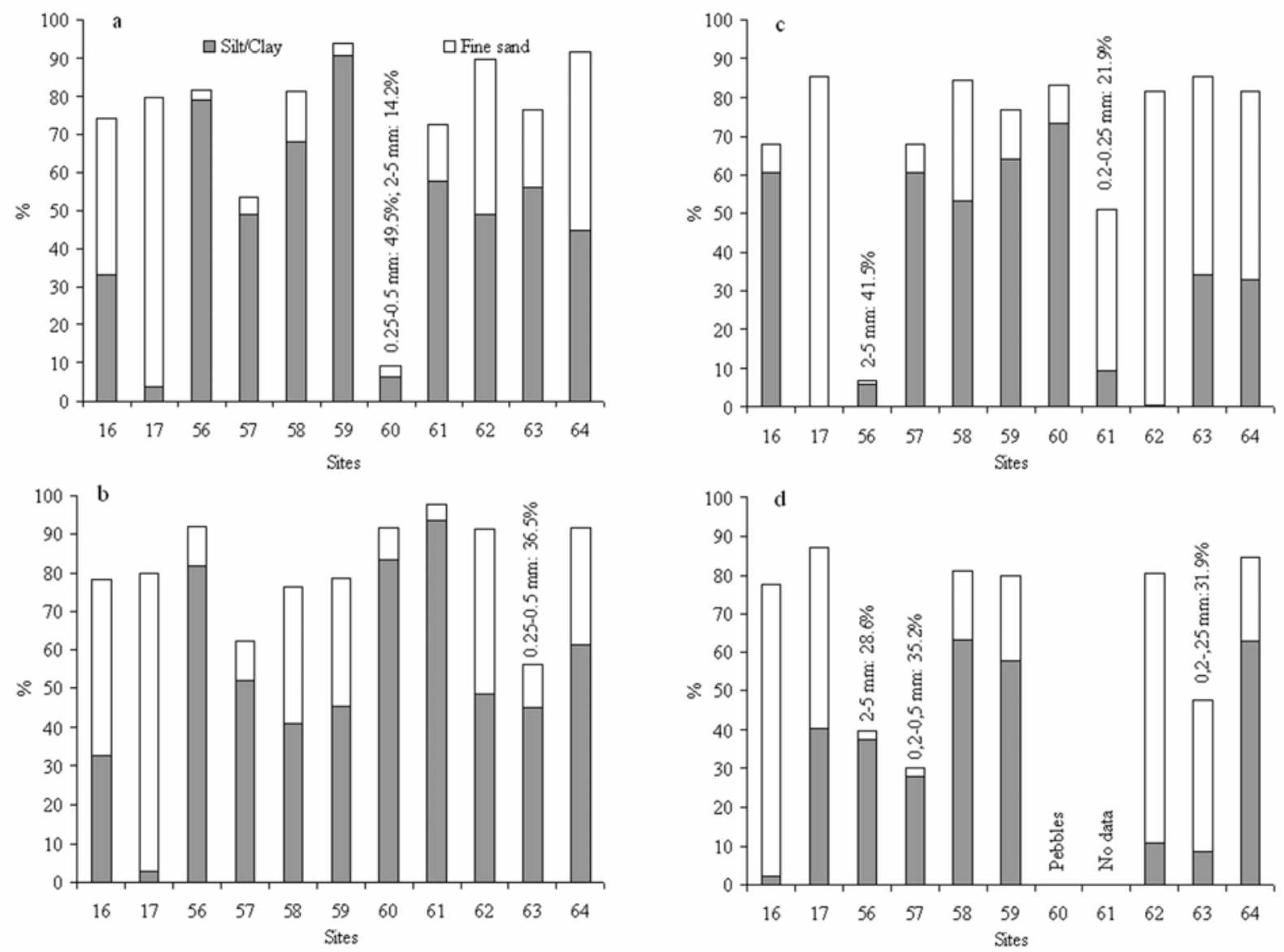

Figure 3: Seasonal variations in silt/clay $(<63 \mu \mathrm{m})$ and fine sand $(100 \mu \mathrm{m}<$ size particle $<200 \mu \mathrm{m}$ ) contents in (a) February, (b) June, (c) September and (d) December 2001 in the North Channel. Contribution of other granulometric classes were presented when necessary. 


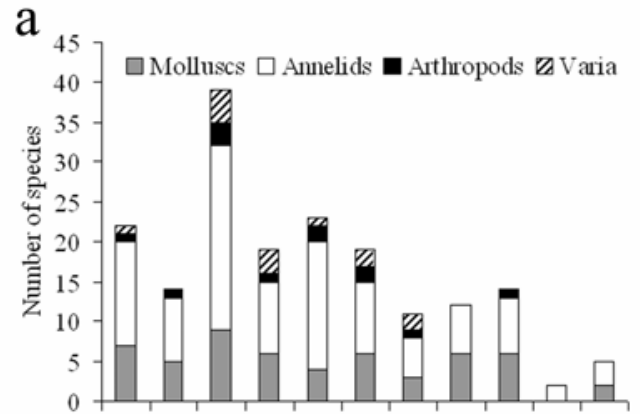

$\begin{array}{lllllllllll}16 & 17 & 56 & 57 & 58 & 59 & 60 & 61 & 62 & 63 & 64\end{array}$

$\mathrm{b}$

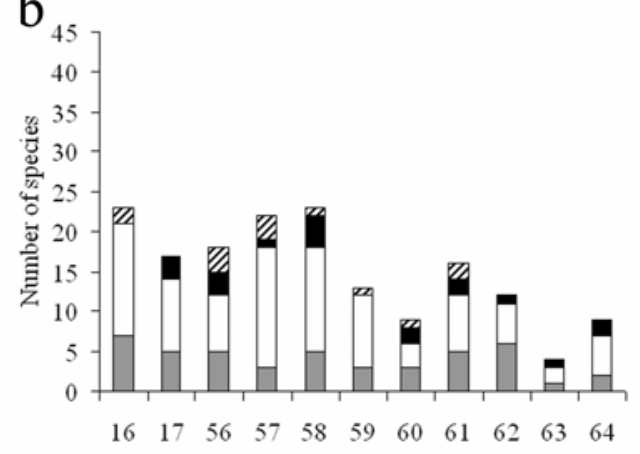

C

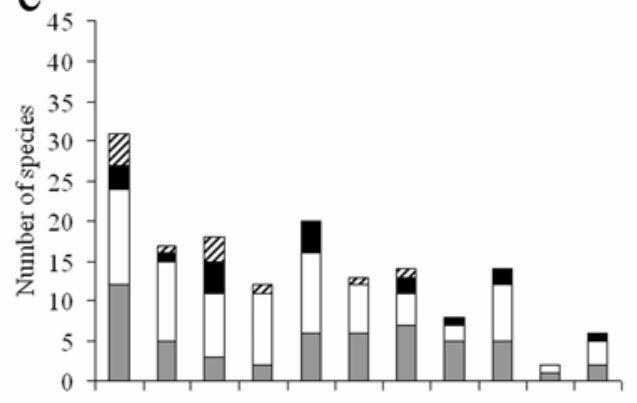

d

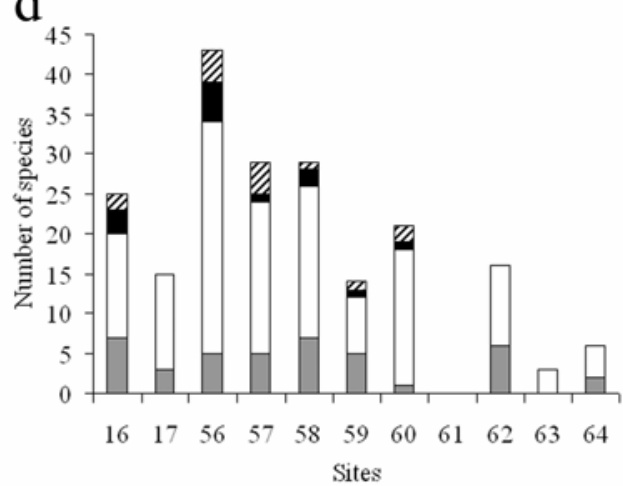

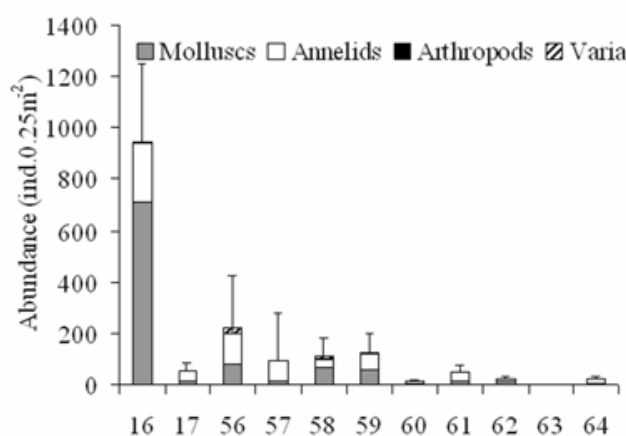
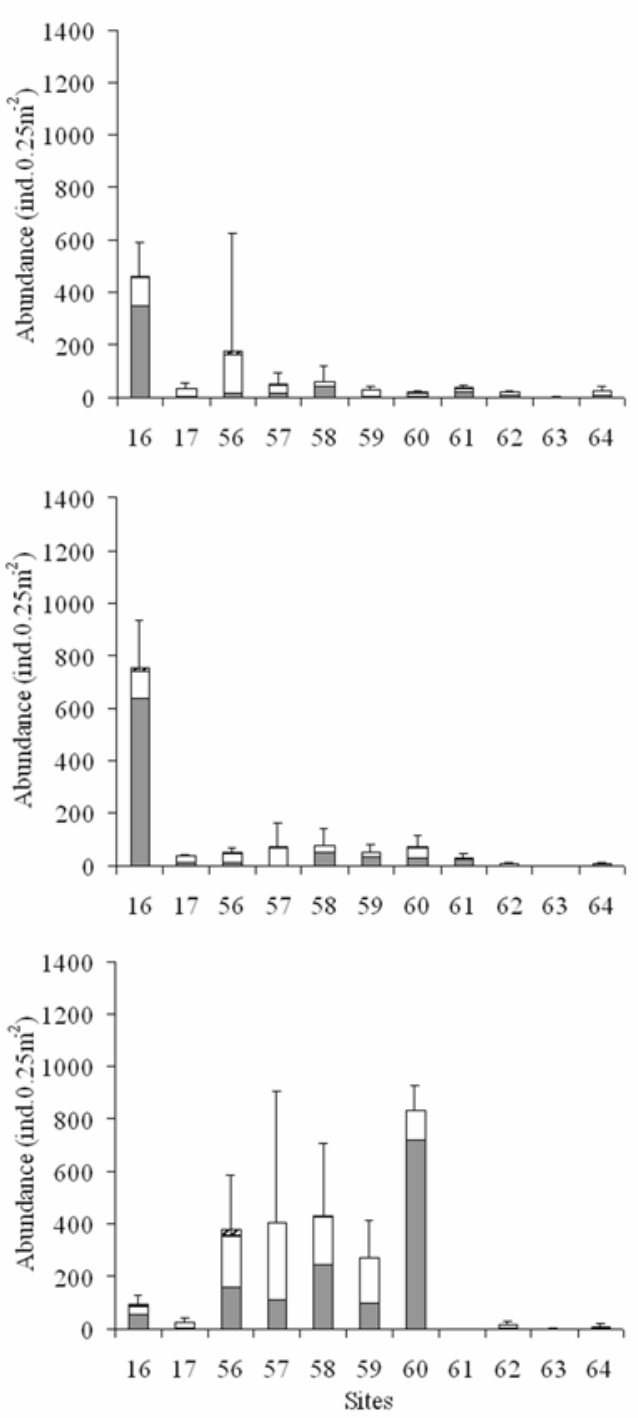

Figure 4: Seasonal variations in (1) number of species and (2) abundances (+SD) of macrobenthos in (a) February, (b) June, (c) September and (d) December 2001 in the North Channel. 


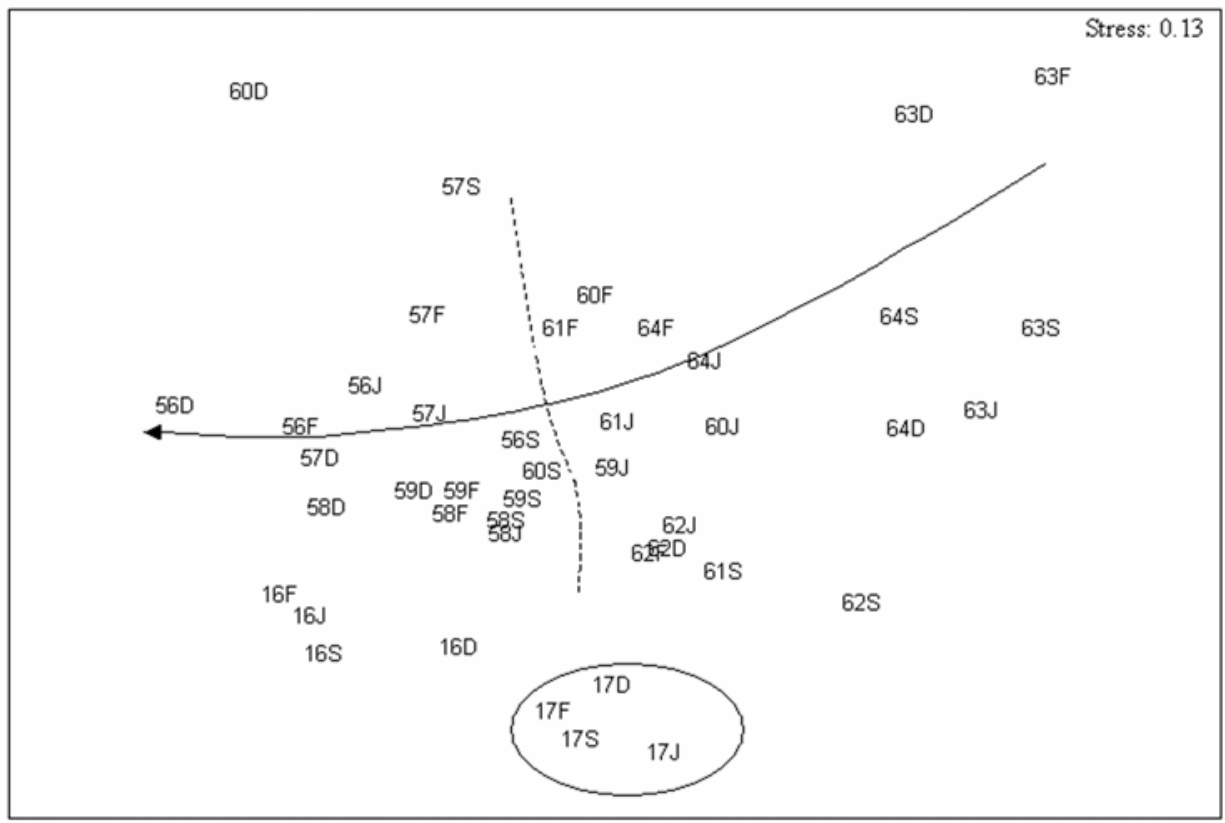

Figure 5: Two-dimensional configuration for MDS ordination of macrofaunal assemblages (F: February samples, J: June samples, S: September samples and D: December samples). 

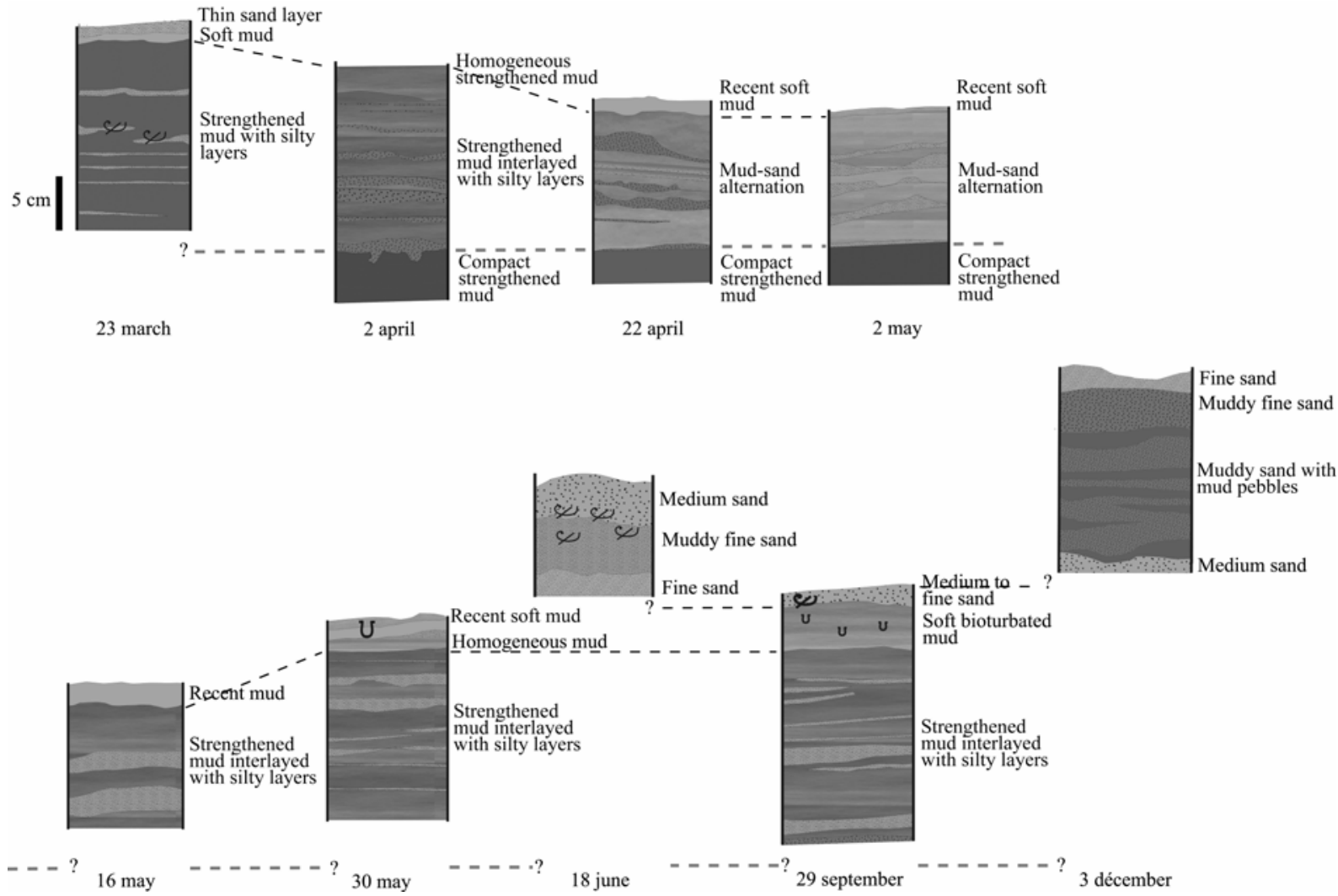

Figure 6: Lithofacies variations, with correspondence between layers (specified by the symbol "?” when hypothetic), at site 62 from March to December 2002. Considering the basal compacted strengthened mud as a reference layer, cores were arranged one compared to the others. Upward lines suggest deposition events and downward lines, compaction and/or erosion phenomena. Symbols show the presence of shells ( $S$ ) and burrows ( $U$ ). 


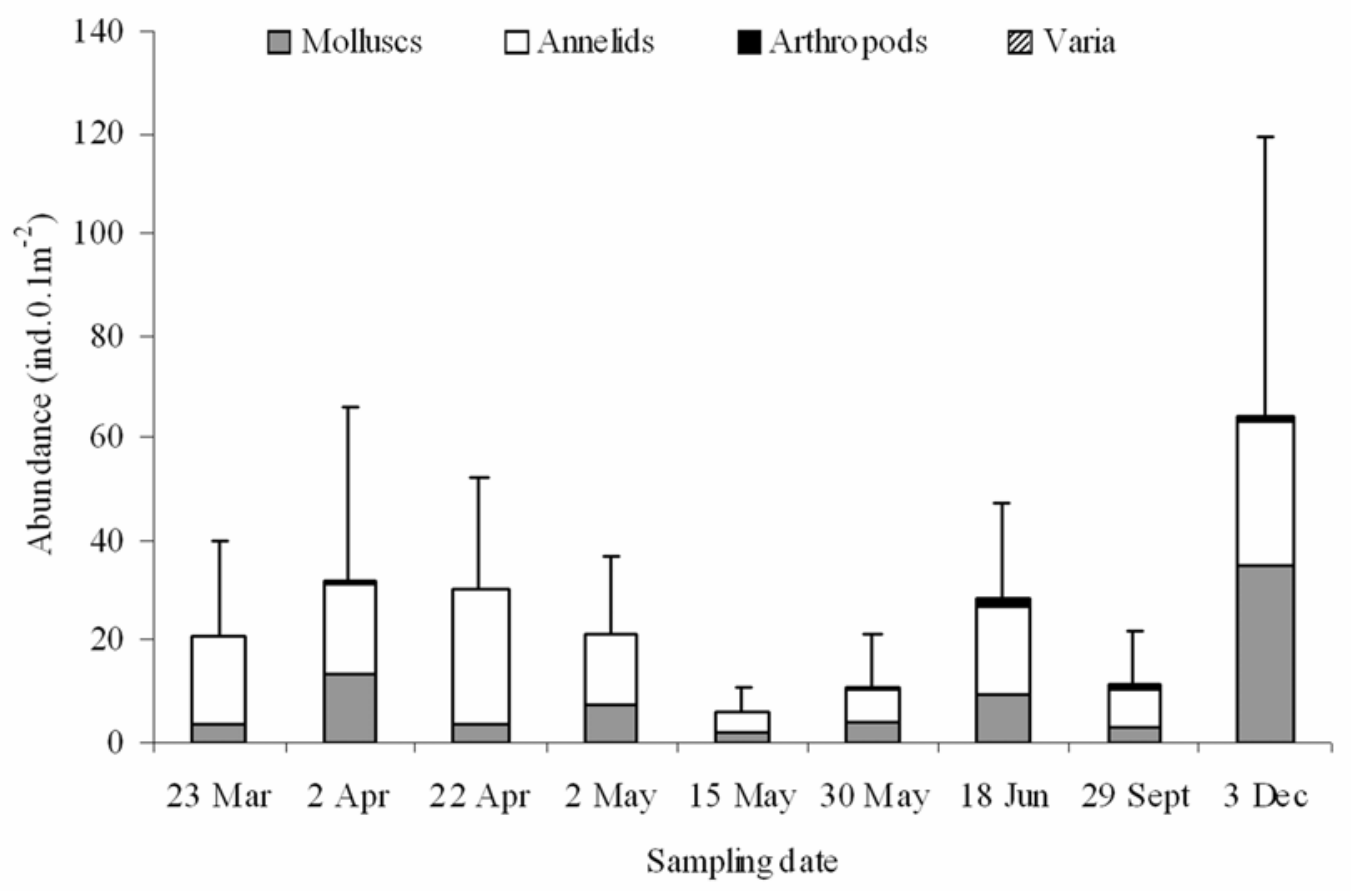

Figure 7: Change of the total macrobenthic density at site 62 along the year 2002. 


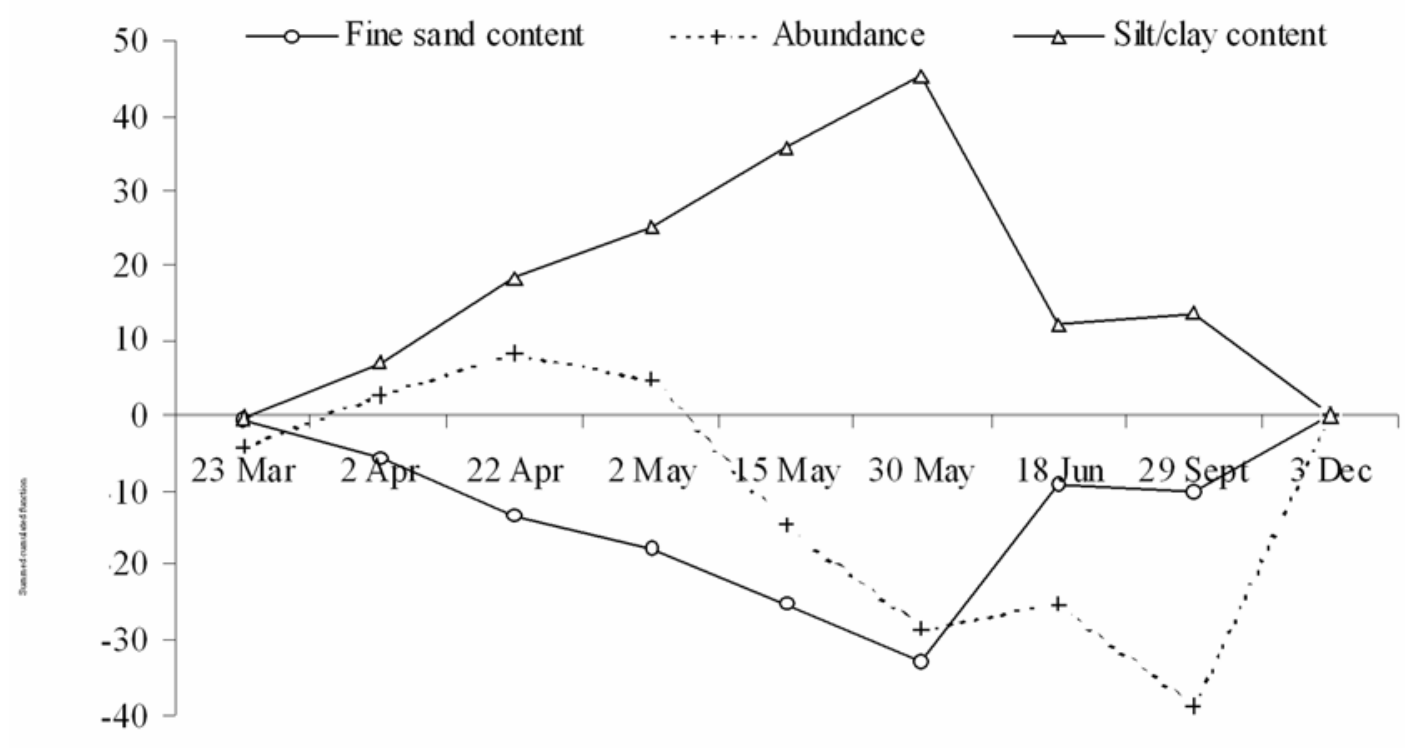

Time

Figure 8: Summed cumulated function of the mean fine sand and silt/clay contents and the mean abundance. 

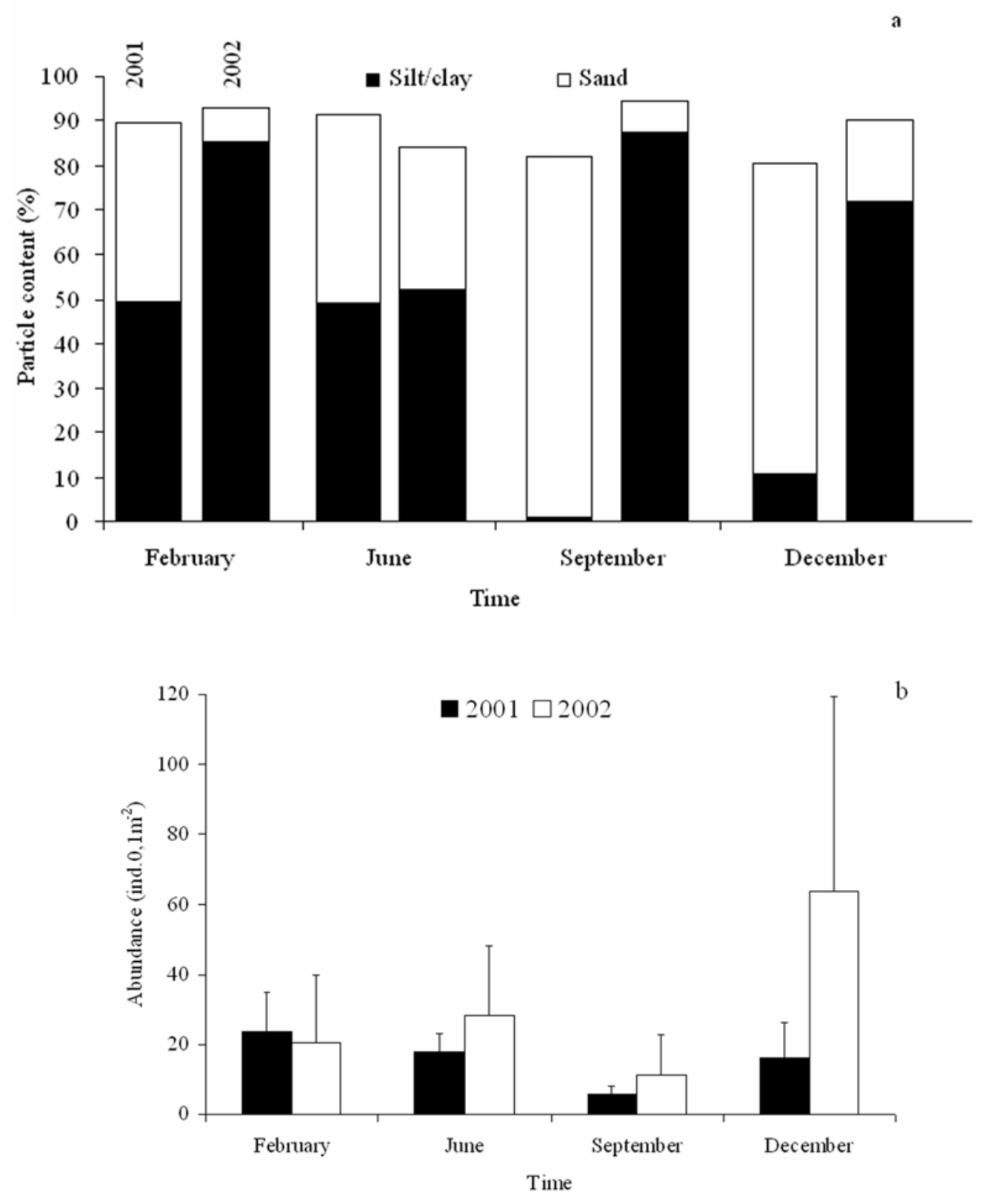

Figure 9: Inter-annual changes in fine sand and silt/clay contents $(\%, a)$ and in average macrobenthic abundance \pm SD (ind. $0.1 \mathrm{~m}^{-2}$, b) in 2001 and 2002 at site 62 . Abundances values recorded in 2001 were standardized to $0.1 \mathrm{~m}^{-2}$. 